\title{
Stimulation of progesterone production in human granulosa-lutein cells by lipoproteins: evidence for cholesterol-independent actions of high-density lipoproteins
}

\author{
J Ragoobir ${ }^{1}$, D R E Abayasekara ${ }^{2}$, K R Bruckdorfer ${ }^{1}$ \\ and A E Michael ${ }^{1,2}$ \\ ${ }^{1}$ Department of Biochemistry and Molecular Biology, Royal Free and University College Medical School, University College London, Rowland Hill Street, \\ London NW3 2PF, UK \\ ${ }^{2}$ Reproduction \& Development Group, Department of Veterinary Basic Sciences, Royal Veterinary College, Royal College Street, London NW1 0TU, UK \\ (Requests for offprints should be addressed to J Ragoobir who is now at the Department of Veterinary Basic Sciences, Royal Veterinary College, \\ Royal College Street, London NW1 OTU, UK; Email: jragoobir@rvc.ac.uk)
}

\begin{abstract}
Low-density lipoproteins (LDL) have been consistently reported to stimulate ovarian steroidogenesis, apparently by the provision of cholesterol as a steroidogenic substrate. Recent studies suggest that high-density lipoproteins (HDL) can also deliver cholesterol to support progesterone synthesis in human granulosa-lutein cells. Therefore, this study investigated the contributions of (i) cholesterol delivery, (ii) cyclic AMP and (iii) protein kinase C (PKC) in the steroidogenic responses of human granulosa-lutein cells to HDL and LDL. Over a 24-h treatment incubation, HDL stimulated a larger increase in progesterone output than did LDL at equivalent cholesterol concentrations. Moreover, at equal protein concentrations $(100 \mu \mathrm{g}$ protein/ml), HDL doubled progesterone production by cells co-treated with a maximally effective concentration
\end{abstract}

of 22R-hydroxycholesterol, whereas LDL had no effect on the progesterone response to this membrane-permeable sterol. These observations indicate that the progesterone response to HDL is not solely due to the delivery of cholesterol as a steroidogenic substrate. Over $24 \mathrm{~h}$, the stimulation of progesterone synthesis by HDL was additive with the response to a maximally effective concentration of dibutyryl-cAMP, but was unaffected by the downregulation of PKC activity (by chronic pre-treatment with a tumour-promoting phorbol ester). We have concluded that HDL appears to stimulate progesterone production in human granulosa-lutein cells by a mechanism not solely reliant on cholesterol delivery.

Journal of Endocrinology (2002) 173, 103-111

\section{Introduction}

Vascularized ovarian tissues, such as the theca interna of developing ovarian follicles and the corpus luteum (CL), are exposed to circulating plasma lipoproteins. Moreover, follicular fluid from pre-ovulatory follicles has been shown to contain high-density lipoproteins (HDL) (Simpson et al. 1980, Volpe et al. 1991, Jaspard et al. 1996, 1997) which may have a bearing on the function of the surrounding granulosa cells.

In granulosa cells and luteal cells obtained from a range of non-primate species, both low-density lipoproteins (LDL) and HDL have been shown to stimulate steroidogenesis in granulosa and luteal cells (Savion et al. 1981, 1982, Schuler et al. 1981, Hwang \& Menon 1983, Veldhuis et al. 1984, Wiltbank et al. 1990, Bao et al. 1995, Brannian 1997). In human and in non-human primates, the effects of lipoproteins are less clearly defined. Studies in human and non-human primate CL have suggested that
LDL serve as the main source of lipoprotein-derived cholesterol for luteal progesterone biosynthesis (Carr et al. 1981, Tureck \& Strauss 1982, Brannian et al. 1992, Brannian \& Stouffer 1993). However, while a number of studies have consistently reported the ability of LDL to stimulate progesterone production by the human CL and in human granulosa-lutein cells in vitro (e.g. Carr et al. 1981, Tureck \& Strauss 1982, Soto et al. 1984, Golos et al. 1985), the effects of HDL have varied dramatically between different studies. Initial studies found that HDL had no significant effect on progesterone synthesis in the human CL (Simpson et al. 1980, Carr et al. 1981, Tureck \& Strauss 1982), while more recent studies have reported increased progesterone synthesis by luteinized cells treated with HDL (Enk et al. 1987, Parinaud et al. 1987, Volpe et al. 1991, Azhar et al. 1998).

Although the principal function of HDL is to mediate the reverse transport of cholesterol from peripheral tissues to the liver (Pieters et al. 1994, Barter \& Rye 1996), HDL 
is also capable of delivering cholesterol into steroidogenic cells, including human granulosa-lutein cells (Azhar et al. 1998). While LDL delivers cholesterol via a receptormediated endocytic pathway (Brown et al. 1979, Golos \& Strauss 1985, Golos et al. 1985, 1986, Foster et al. 1993), the delivery of cholesterol from HDL particles is mediated through a selective uptake pathway via the scavenger receptor, class B, type I (SR-BI) (Fielding \& Fielding 1995, Acton et al. 1996, Babitt et al. 1997, Reaven et al. 1998, Graf et al. 1999). Hence, the recent localization of SR-BI expression to ovarian tissues (Acton et al. 1996, Reaven et al. 1998), together with the identification of mRNA encoding the apolipoprotein components of HDL in the human ovary (Pascher \& Sturm 1997), supports a possible role for HDL in the control of human ovarian steroidogenesis.

While the uptake of lipoprotein-derived cholesterol is important in providing steroidogenic cells with a sterol substrate from which to synthesize steroid hormones, the primary endocrine stimulus to ovarian and testicular steroidogenesis is provided by the gonadotrophins. Within steroidogenic gonadal cells, luteinizing hormone (LH), follicle-stimulating hormone (FSH) and human chorionic gonadotrophin (hCG) each appear to act predominantly via the cyclic adenosine- $3^{\prime}, 5^{\prime}$-monophosphate (cAMP)protein kinase A (PKA) transmembrane signalling pathway (reviewed by Cooke 1990, Leung \& Steele 1992, Davis 1994, Cooke 1999). Additional signalling pathways implicated in the steroidogenic actions of the gonadotrophins include the phosphoinositide-phospholipase C (PI-PLC) pathway and activation of protein kinase $\mathrm{C}$ (PKC) pathway (reviewed by Cooke 1990, Leung \& Steele 1992, Davis 1994, Cooke 1999).

Given that luteinized human ovarian cells are exposed to both classes of lipoproteins in vivo, this study compared the effects of HDL and LDL on progesterone production by human granulosa-lutein cells, and assessed the potential cellular mechanisms by which HDL may increase progesterone output. Specifically, the contributions of cholesterol delivery, cAMP and PKC to the steroidogenic actions of HDL and LDL were determined.

\section{Materials and Methods}

\section{Materials}

Progesterone antiserum was supplied by the Central Veterinary Laboratories (Surrey, UK) while $\left[1,2,6,7-{ }^{3} \mathrm{H}\right]-$ progesterone was purchased from Amersham International (Aylesbury, Buckinghamshire, UK). Dulbecco's modified Eagles medium containing Ham's $\mathrm{F}_{12}$ medium (1:1 (v/v) DMEM: $\left.F_{12}\right)$, FCS, L-glutamine, penicillin, PBS and streptomycin were each obtained from GIBCO-BRL Life Technologies (Cheshire, UK) and plastic culture dishes from Costar (High Wycombe, Buckinghamshire, UK). hCG (CR127) was provided by NIDDK (National
Institutes of Health, Bethesda, MD, USA). Percoll, dibutyryl-cAMP (db-cAMP), 4 $\alpha$-phorbol-12-myristate13-acetate (PMA), 4 $\beta$-PMA, 22R-hydroxycholesterol (22ROHC) and assay kits for the determination of cholesterol content in lipoproteins were purchased from Sigma Chemical Co. (Poole, Dorset, UK). All other chemicals and organic solvents were supplied by Merck (Poole, Dorset, UK).

22ROHC was dissolved at a stock concentration of $30 \mathrm{mM}$ in ethanol, whereas $4 \alpha$ - and $4 \beta$-PMA were each prepared at concentrations of $10 \mathrm{mM}$ in DMSO. 22ROHC, $4 \alpha-$ and $4 \beta-\mathrm{PMA}$ were each diluted into culture medium to the stated concentrations immediately prior to use, ensuring that the final concentration of organic solvent remained $=0 \cdot 1 \%(\mathrm{v} / \mathrm{v})$.

\section{Isolation and preparation of human granulosa cells}

Follicular aspirates were obtained from women undergoing controlled ovarian hyperstimulation for assisted conception at the Lister Private Hospital (Chelsea, London) and Hallam Women's Clinic (Harley Street, London). (All patients gave informed consent for collection of cells in accordance with the Declaration of Helsinki, and all procedures were approved by the relevant local ethics committee.) Pituitary down-regulation was achieved by the administration of a gonadotrophin-releasing hormone $(\mathrm{GnRH})$ analogue (buserelin acetate; Suprefact, Hoechst, Hounslow, Middlesex, UK) for either 3 or 10 days, commencing on the first day of the menstrual cycle (corresponding to the short and long down-regulation protocol respectively). Human menopausal gonadotrophin (hMG; Pergonal, Serono, Feltham, Middlesex, UK) was co-administered for up to 10 days. After assessment of follicle development by ultrasonography and plasma oestradiol assays, hCG (10 000-20 000 IU; Pregnyl, Organon, Cambridge, UK) was administered approximately $36 \mathrm{~h}$ prior to oocyte retrieval. During oocyte retrieval, the oocytes were aspirated transvaginally and flushed with Earl's balanced salt solution supplemented with antibiotics. Aspirates were transported in sterile flasks to the Royal Free Campus of Royal Free and University College Medical School within $3 \mathrm{~h}$ of oocyte retrieval.

Granulosa cells were isolated from follicular aspirates using 60\% (v/v) Percoll as previously described (Webley et al. 1988). For each individual experiment, cells from multiple follicles (3-14), all from the same patient, were pooled. However, on no occasion were cells harvested from different patients combined. The number of granulosa-lutein cells isolated from each patient ranged from $1.2 \times 10^{6}$ cells to $9 \cdot 4 \times 10^{6}$ cells, dependent upon the precise number of follicles aspirated.

Granulosa cells were cultured for $72 \mathrm{~h}$ at a density of $5 \times 10^{4}$ viable cells $/ \mathrm{ml}$ in DMEM: $\mathrm{F}_{12}$ medium supplemented with $10 \%$ (v/v) FCS, $2 \mathrm{mM}$ L-glutamine, penicillin $(87000 \mathrm{IU} / \mathrm{l})$ and streptomycin $(87 \mathrm{mg} / \mathrm{l})$. Cells 
were plated in 96-well sterile culture plates and incubated at $37^{\circ} \mathrm{C}$ in a humidified atmosphere of $5 \%(\mathrm{v} / \mathrm{v}) \mathrm{CO}_{2}$ in air. As stated below, all experiments were initiated on day 3 of culture under serum-free conditions unless stated otherwise.

\section{Lipoprotein isolation}

Blood from healthy fasted human volunteers was drawn into a syringe containing $63 \mathrm{mM}$ EDTA and $42 \mu \mathrm{M}$ diethylenediamino-pentaacetic acid (DTPA) at a ratio (by volume) of 1:20 anticoagulant:blood. LDL and HDL were isolated from human plasma by sequential ultracentrifugation as previously described (Havel et al. 1955). The isolated lipoproteins were dialysed at $4{ }^{\circ} \mathrm{C}$ against $12 \mathrm{mM}$ Tris ( $\mathrm{pH} 7 \cdot 4$ ) with three changes of dialysis buffer over $12 \mathrm{~h}$. The protein concentration of each lipoprotein preparation was determined using the modified method of Lowry (Markwell et al. 1978), with stock solutions of BSA as standard. Oxidation of the lipoproteins was assessed by measuring thiobarbituric acid reactive substances (TBARS) using a spectrophotometric method as previously described (Janero 1990). The HDL and LDL preparations used in this study had values of $<0.6 \mathrm{nmol}$ TBARS/mg protein, indicating that no significant oxidation had taken place.

\section{Experimental designs}

To assess the concentration-dependent effects of lipoproteins on basal progesterone production, cells were treated for $24 \mathrm{~h}$ on day 3 of culture in serum-free DMEM:Ham's $\mathrm{F}_{12}$ medium containing $\mathrm{HDL}$ or LDL either at equal protein concentrations $(0-400 \mu \mathrm{g} / \mathrm{ml})$ or at equivalent cholesterol concentrations $(0-400 \mu \mathrm{g} / \mathrm{ml})$.

Based on the results obtained in these studies, for all subsequent studies, both HDL and LDL were used at a fixed concentration of $100 \mu \mathrm{g}$ protein $/ \mathrm{ml}$.

To establish whether each lipoprotein could enhance the steroidogenic action of $22 \mathrm{ROHC}$, cells were incubated in serum-free medium for $24 \mathrm{~h}$ with a range of concentrations of $22 \mathrm{ROHC}(0-30 \mu \mathrm{M})$, each in the presence and absence of LDL or HDL.

To establish the time course of the progesterone response to each of the lipoproteins, cells were treated for 2 , 4 and $24 \mathrm{~h}$ on day 3 of culture with HDL and LDL. Since trophic hormones are known to induce the expression of lipoprotein receptors (Cummings et al. 1982, Ohashi et al. 1982, Golos \& Strauss 1985, Golos et al. 1985, 1986, Takagi \& Strauss 1989, Rudling et al. 1990, Foster et al. 1993), prior exposure of luteinizing granulosa cells to hCG might be expected to accelerate or enhance the steroidogenic response to lipoproteins as compared with naive cells that have not been pre-exposed to hCG. To test this hypothesis, cells were pre-incubated for $24 \mathrm{~h}$ (starting on day 2 of culture) in serum-supplemented medium containing hCG $(100 \mathrm{ng} / \mathrm{ml})$, and then challenged as above on day 3 of culture with HDL or LDL for 2, 4 and $24 \mathrm{~h}$ in serum-free medium.

To explore the signal transduction pathways involved in the steroidogenic action of the lipoproteins, cells were treated for $24 \mathrm{~h}$ on day 3 of culture in serum-free medium containing HDL and LDL, each in the presence and absence of a maximally effective concentration of the membrane-permeable cAMP analogue, db-cAMP (1 mM) (Abayasekara et al. 1993a). In a final series of experiments, designed to investigate the potential involvement of PKC in lipoprotein-stimulated progesterone production, cells were pre-treated for $20 \mathrm{~h}$ (commencing on day 2 of culture) in serum-supplemented medium with DMSO, $100 \mathrm{nM} 4 \alpha$-PMA or $100 \mathrm{nM} 4 \beta$-PMA before being challenged for $24 \mathrm{~h}$ in serum-free medium on day 3 of culture with HDL and LDL. (Previous studies in our laboratories have confirmed that this treatment protocol with the active, tumour-promoting $4 \beta$-phorbol ester down-regulates PKC activity by more than $90 \%$ whereas the inactive $4 \alpha$-phorbol stereoisomer has no effect on this serine/threonine kinase (Abayasekara et al. 1993b).)

Experiments were routinely terminated by the addition of $107 \mathrm{mM}$ perchloric acid to each well prior to transfer of the culture plates to be stored at $-20{ }^{\circ} \mathrm{C}$ pending assay. Immediately prior to assay of progesterone, samples were thawed and neutralized by the addition of $154 \mathrm{mM}$ tripotassium orthophosphate.

\section{Radioimmunoassay}

Progesterone concentrations were determined in lipoprotein samples and in spent culture medium as previously described (Pallikaros et al. 1995). Intra- and inter-assay coefficients of variation were $6 \cdot 7 \%$ and $10 \cdot 8 \%$ respectively at $38 \%$ binding, with a working range of $0.5-15.9 \mathrm{nM}$. HDL and LDL had endogenous progesterone concentrations of $<0.5 \mathrm{nM}$.

\section{Statistics}

The majority of experimental results are presented as mean \pm S.E.M. values internally referenced with the relevant experimental control standardized to $100 \%$. However, all statistical analyses were performed on nonreferenced data either using one-way ANOVA with repeated measures (followed by Dunnet's multiple comparison, Bonferroni's multiple $t$-tests or the Tukey post hoc test) or using two-way ANOVA, as appropriate to the experimental design. All statistical analyses were performed using GraphPad Prism2 software (San Diego, CA, USA) and $P$ values of less than 0.05 were accepted as significant in each case. Each experiment was repeated at least three times using cells from a different patient on each occasion. 


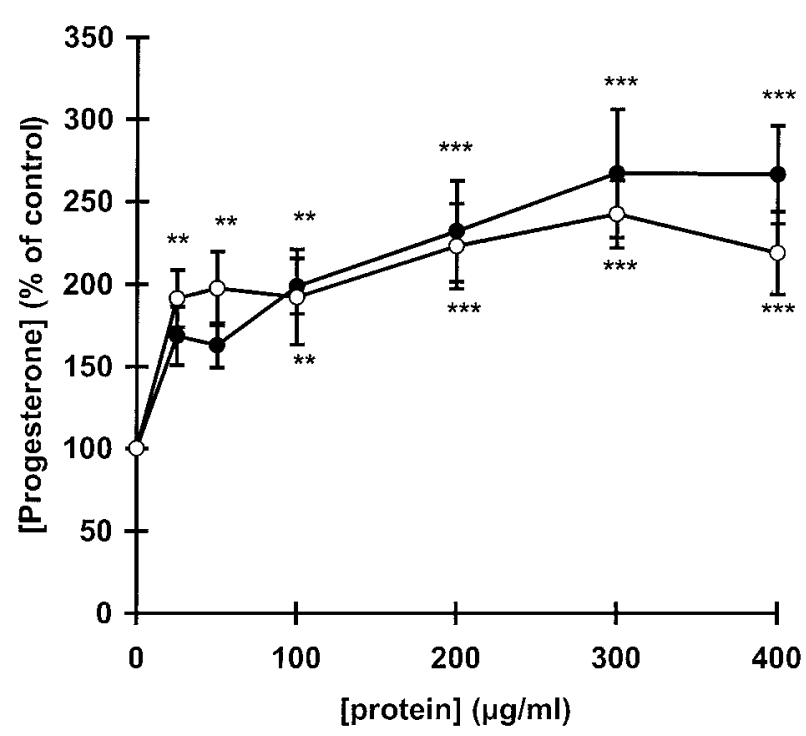

Figure 1 The concentration-dependent effects of HDL and LDL on progesterone production at equal protein concentrations. Granulosa-lutein cells were incubated on day 3 of culture for $24 \mathrm{~h}$ in serum-free medium containing $0-400 \mu \mathrm{g}$ protein $/ \mathrm{ml}$ of $\mathrm{HDL}$ (-) or LDL (O). Data are presented as mean ( \pm S.E.M.) of eight independent experiments. ${ }^{* *} P<0.01$ and ${ }^{* *} P<0 \cdot 001$ for each lipoprotein relative to progesterone production at $0 \mu \mathrm{g}$ protein $/ \mathrm{ml}$.

\section{Results}

Concentration-dependent effects of $H D L$ and $L D L$

In the first series of experiments, human granulosa-lutein cells were treated for $24 \mathrm{~h}$ on day 3 of culture with LDL and HDL at equal concentrations of apolipoprotein (25$400 \mu \mathrm{g}$ protein $/ \mathrm{ml})$. Both lipoproteins stimulated comparable concentration-dependent increases in progesterone synthesis which were maximal at $100 \mu \mathrm{g}$ protein $/ \mathrm{ml}(n=8$; $P<0 \cdot 01$; Fig. 1). In the second experimental series, cells were again stimulated with a range of concentrations of LDL and HDL, but in this second experimental series, plasma lipoproteins were presented to cells at concentrations where the cholesterol contents of each were equal. At concentrations equivalent to $50-400 \mu \mathrm{g}$ cholesterol $/ \mathrm{ml}$, HDL stimulated progesterone production by up to $2 \cdot 4 \pm 0 \cdot 3$-fold $(n=5 ; \quad P<0 \cdot 001)$ while LDL stimulated progesterone synthesis by up to $1.9 \pm 0 \cdot 2$-fold $(n=5$; $P<0 \cdot 01$; Fig. 2). The progesterone responses to HDL were consistently and significantly greater than those to LDL at equal cholesterol concentrations of 100, 200 and $400 \mu \mathrm{g} /$ $\mathrm{ml}(P<0 \cdot 05$; Fig. 2).

Effects of HDL and LDL on the steroidogenic response to $22 \mathrm{ROHC}$

In the absence of additional lipoproteins, 22ROHC elicited a concentration-dependent increase in progesterone synthesis which was maximal $(2 \cdot 6 \pm 0 \cdot 2$-fold $)$ at a

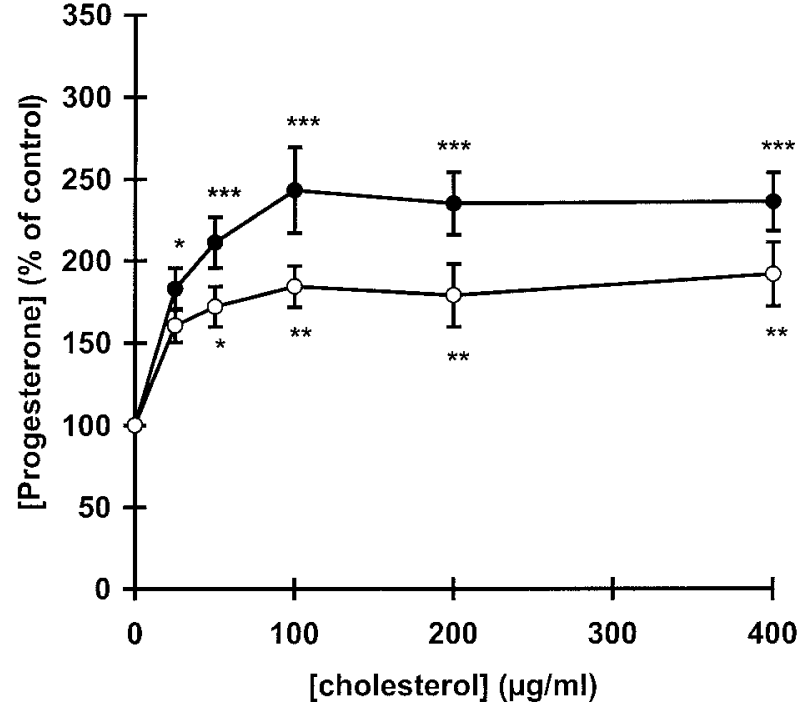

Figure 2 The concentration-dependent effect of HDL and LDL on progesterone synthesis at equal cholesterol concentrations. Granulosa-lutein cells were incubated on day 3 of culture for $24 \mathrm{~h}$ in serum-free medium containing $0-400 \mu \mathrm{g}$ cholesterol/ml of HDL

(-) or LDL (O). Data are presented as mean ( \pm S.E.M.) of five independent experiments. ${ }^{*} P<0 \cdot 05,{ }^{*} P<00 \cdot 01$ and ${ }^{* *}{ }^{*} P<0 \cdot 001$ for each lipoprotein relative to progesterone production at $0 \mu \mathrm{g}$ protein $/ \mathrm{ml}$.

concentration of $10 \mu \mathrm{M} 22 \mathrm{ROHC}(n=8 ; P<0 \cdot 01$; Fig. 3$)$. Co-treatment with a maximally effective concentration of HDL significantly enhanced the progesterone responses to $22 \mathrm{ROHC}$ at concentrations of 3,10 and $30 \mu \mathrm{M}(n=8$; $P<0 \cdot 01$; Fig. 3). In contrast, while treatment with a maximally effective concentration of LDL doubled progesterone production in the absence of 22ROHC, progesterone synthesis in the presence of $\geq 0 \cdot 3 \mu \mathrm{M}$ 22ROHC was unaffected by co-treatment with LDL.

Time-dependent effects of lipoproteins; influence of pre-treatment with hCG

While the effects of HDL and LDL on basal progesterone production (on day 3 of culture) were insignificant at $2 \mathrm{~h}$ and $4 \mathrm{~h}$ of treatment, both HDL and LDL stimulated comparable increases in progesterone synthesis at $24 \mathrm{~h}$ of $5 \cdot 0 \pm 1 \cdot 0$-fold and $6 \cdot 5 \pm 2 \cdot 3$-fold, respectively, relative to control progesterone production in the absence of lipoproteins at the matched time-point $(n=3 ; P<0 \cdot 05$; Fig. 4).

Pre-incubation of granulosa-lutein cells for $24 \mathrm{~h}$ on day 2 of culture with hCG $(100 \mathrm{ng} / \mathrm{ml})$ enhanced subsequent progesterone output on day 3 of culture (by $2 \cdot 6 \pm 0 \cdot 7$-fold relative to naive cells from the same patients), but had no effect on the subsequent abilities of LDL and HDL to stimulate progesterone production. In cells pre-exposed to hCG, HDL and LDL exerted no significant effects on progesterone output at $2 \mathrm{~h}$ and $4 \mathrm{~h}$, but stimulated 


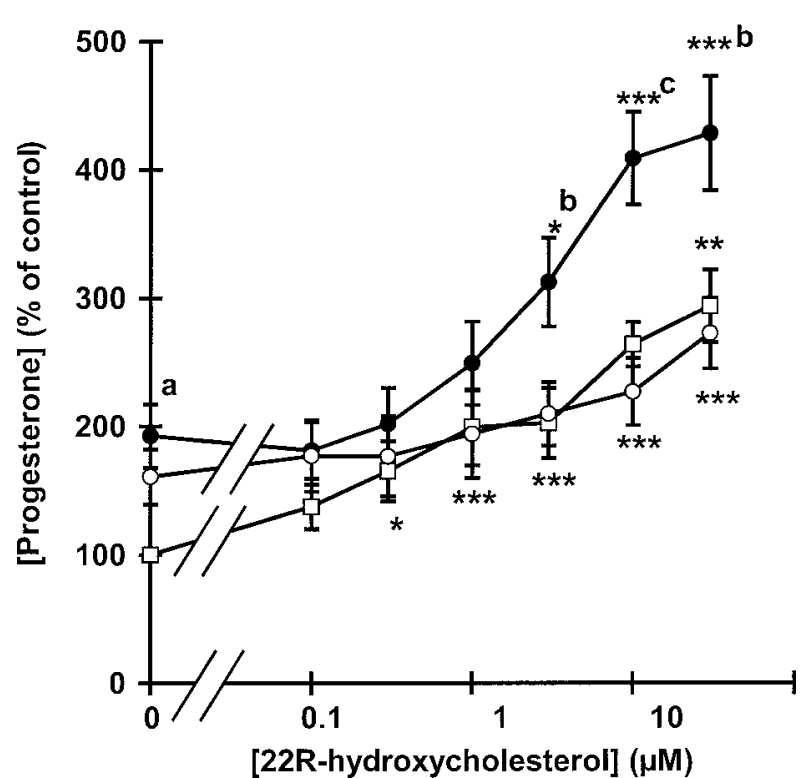

Figure 3 The effects of HDL and LDL on 22R-hydroxycholesterol $(22 \mathrm{ROHC})$ stimulated progesterone production. Granulosa-lutein cells were incubated on day 3 of culture for $24 \mathrm{~h}$ in serum-free medium containing 0-30 $\mu \mathrm{M} 22 \mathrm{ROHC}$ plus lipoprotein vehicle $(\square), \mathrm{HDL}(100 \mu \mathrm{g}$ protein $/ \mathrm{ml} ; \bullet)$ or LDL $(100 \mu \mathrm{g}$ protein $/ \mathrm{ml} ; \bigcirc)$. Data are presented as mean ( \pm S.E.M.) of eight independent experiments. ${ }^{*} P<0 \cdot 05,{ }^{* *} P<0 \cdot 01$ and ${ }^{* * *} P<0 \cdot 001$ for each lipoprotein relative to progesterone production at $0 \mu \mathrm{M} 22 \mathrm{ROHC}$ in the presence of the appropriate lipoprotein. ${ }^{\mathrm{a}} P<0 \cdot 05,{ }^{\mathrm{b}} P<0 \cdot 01$ and ${ }^{c} P<0.001$ relative to progesterone production at the appropriate concentration of $22 \mathrm{ROHC}$ without lipoproteins.

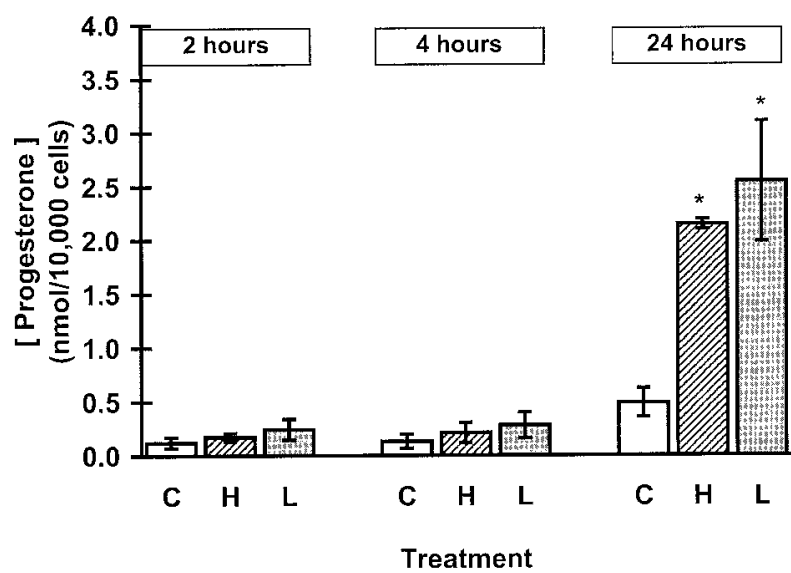

Figure 4 The time-dependent effects of $\mathrm{HDL}$ and $\mathrm{LDL}$ on progesterone production. Granulosa-lutein cells were incubated on day 3 of culture for 2, 4 and $24 \mathrm{~h}$ in serum-free medium containing lipoprotein vehicle (C: open bar), HDL $(100 \mu \mathrm{g}$ protein/ml; H: hatched bar) or LDL (100 $\mu$ g protein/ml; L: solid bar). Data are presented as mean ( \pm S.E.M.) of three independent experiments. ${ }^{*} P<0.05$ for lipoprotein-stimulated progesterone production versus progesterone production in the absence of lipoprotein at the same time point.

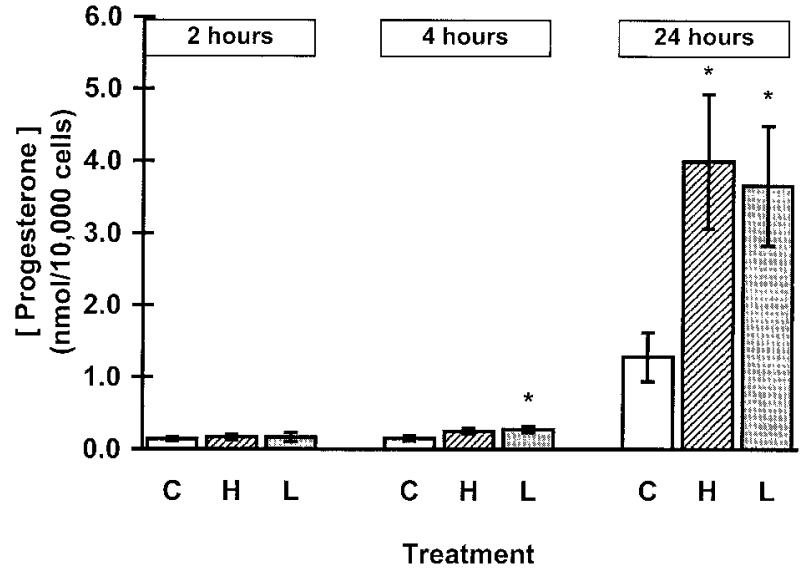

Figure 5 The time-dependent effects of HDL and LDL on progesterone production following $24 \mathrm{~h}$ pre-exposure of cells to hCG. Granulosa-lutein cells were incubated for $24 \mathrm{~h}$ on day 2 of culture with hCG $(100 \mathrm{ng} / \mathrm{nl})$ before being treated on day 3 of culture for 2, 4 and $24 \mathrm{~h}$ with lipoprotein vehicle (C: open bar), HDL $(100 \mu \mathrm{g}$ protein/ml; H: hatched bar) or LDL $(100 \mu \mathrm{g}$ protein/ml; L: solid bar). Data are presented as mean ( \pm S.E.M.) of three independent experiments. ${ }^{*} P<0 \cdot 05$ for each treatment versus basal progesterone production in the absence of lipoprotein at the same time point.

progesterone production at $24 \mathrm{~h}$ by $3 \cdot 3 \pm 0 \cdot 7$-fold and $3 \cdot 1 \pm 0 \cdot 7$-fold, respectively, relative to the untreated control cells at $24 \mathrm{~h}(n=3 ; P<0 \cdot 05$; Fig. 5$)$. Hence, at $24 \mathrm{~h}$, the fold-responses to each of the lipoproteins in cells pre-treated with hCG did not differ significantly from those in cells that had not been pre-exposed to this gonadotrophin.

\section{Interactive effects of $H D L$ and $c A M P$}

In the absence of lipoproteins, treatment of cells for $24 \mathrm{~h}$ with $1 \mathrm{mM} \mathrm{db}-\mathrm{cAMP}$ stimulated progesterone production by $88 \pm 19 \%(n=6 ; P<0 \cdot 05$; Fig. 6$)$. In the absence of $\mathrm{db}-\mathrm{cAMP}, \mathrm{HDL}$ and LDL increased progesterone output in the same experiments by $2 \cdot 2 \pm 0 \cdot 1$-fold $(P<0 \cdot 01)$ and $2 \cdot 0 \pm 0 \cdot 2$-fold $(P<0 \cdot 05)$ respectively (Fig. 6). In cells co-treated with HDL $+d b-c A M P$ and with $\mathrm{LDL}+\mathrm{db}-$ cAMP, progesterone production was stimulated by $4 \cdot 2 \pm 0 \cdot 4$-fold and $4 \cdot 0 \pm 0 \cdot 5$-fold, respectively, relative to the untreated control cells $(P<0 \cdot 001$; Fig. 6). Hence, co-treatment with either HDL or LDL enhanced progesterone production by $2 \cdot 3 \pm 0 \cdot 2$-fold relative to cells treated with a maximally stimulatory concentration of db-cAMP alone $(P<0 \cdot 001$; Fig. 6$)$.

Role for PKC in the steroidogenic actions of HDL and $L D L$

Pre-treatment of cells for $20 \mathrm{~h}$ with $100 \mathrm{nM} 4 \alpha$-PMA had no effect on basal progesterone production relative to control cells incubated in the presence of $0 \cdot 1 \%(\mathrm{w} / \mathrm{v})$ 


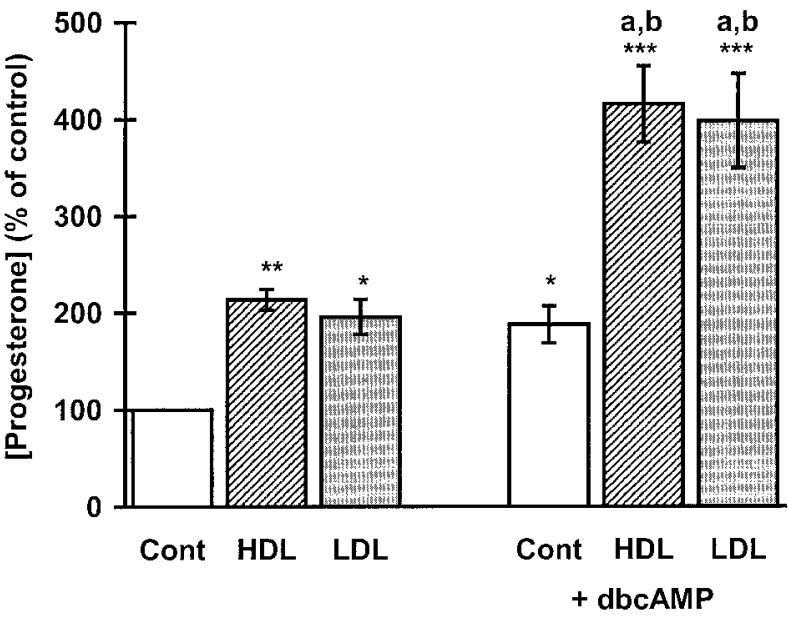

Treatments

Figure 6 Effects of HDL and LDL on dibutyryl cAMP-stimulated progesterone production. Granulosa-lutein cells were incubated on day 3 of culture for $24 \mathrm{~h}$ in serum-free medium in the presence and absence of $1 \mathrm{mM}$ db-cAMP (as indicated) plus lipoprotein vehicle (Cont: open bars), HDL (100 $\mu$ g protein/ml; hatched bars) or LDL (100 $\mu$ g protein/ml; solid bars). Data are presented as mean $\left( \pm\right.$ S.E.) of six independent experiments. ${ }^{*} P<0 \cdot 05,{ }^{*} P<0 \cdot 01$ and ${ }^{* * *} P<0 \cdot 001$ for each treatment versus basal progesterone production in the absence of db-cAMP or lipoproteins. ${ }^{\mathrm{a}} P<0 \cdot 001$ relative to progesterone production in the presence of $\mathrm{db}$-cAMP alone. ${ }^{b} P<0 \cdot 001$ relative to progesterone production in the presence of the appropriate lipoprotein without db-cAMP.

DMSO without phorbol esters (Fig. 7). Moreover, chronic pre-exposure to $4 \alpha$-PMA had no significant effect on the subsequent progesterone responses to either HDL or LDL (Fig. 7). In cells pre-treated with $100 \mathrm{nM} 4 \beta-P M A$, basal progesterone concentrations were enhanced by $44 \pm 9 \%$ $(n=4)$, but the fold-responses to HDL and LDL did not differ significantly from those measured in cells pre-treated with either 4 $\alpha$-PMA or DMSO vehicle (Fig. 7).

\section{Discussion}

The results obtained in this study confirm that HDL can stimulate progesterone synthesis in human granulosalutein cells and indicate that this steroidogenic action of HDL (unlike LDL) is probably not solely due to the delivery of cholesterol as a steroidogenic substrate.

This study provides evidence that at equal protein concentrations, freshly prepared, non-oxidized HDL and LDL are equipotent in stimulating progesterone production by human granulosa-lutein cells. While the stimulation of progesterone production by HDL is consistent with a number of previously published studies (e.g. Enk et al. 1987, Parinaud et al. 1987, Volpe et al. 1991), prior studies have all reported HDL to be less potent than LDL in increasing basal and gonadotrophin-stimulated

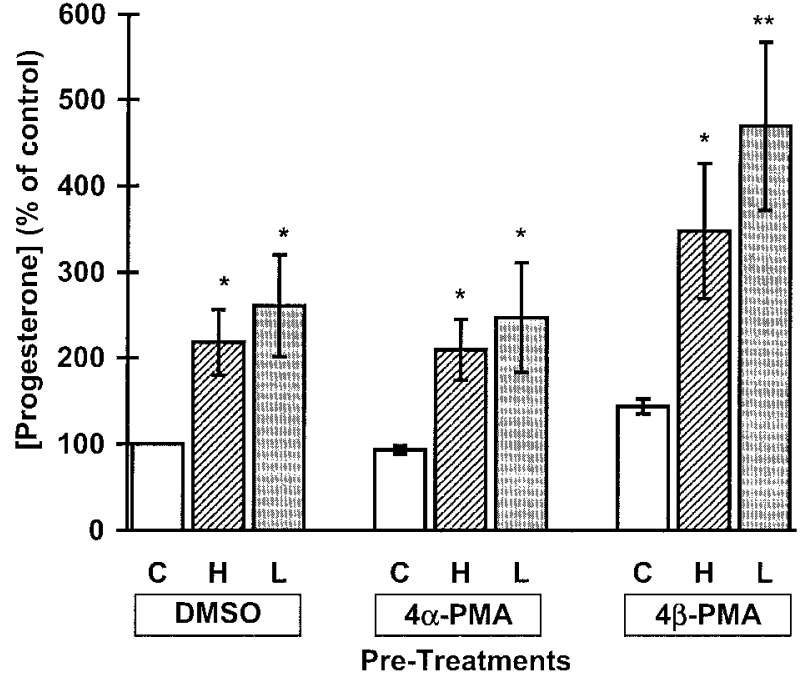

Figure 7 The effects of PKC down-regulation on the progesterone responses to $\mathrm{HDL}$ and LDL. Granulosa-lutein cells were incubated on day 2 of culture for $20 \mathrm{~h}$ in serum-free medium containing (i) $0 \cdot 1 \%(\mathrm{v} / \mathrm{v}) \mathrm{DMSO}$, (ii) $100 \mathrm{nM} 4 \alpha-\mathrm{PMA}$ or (iii) $100 \mathrm{nM} 4 \beta-\mathrm{PMA}$ (as indicated), followed by a $24-\mathrm{h}$ incubation with lipoprotein vehicle (C: open bars), HDL (100 $\mu$ g protein $/ \mathrm{ml}$; H: hatched bars) or LDL (100 $\mu \mathrm{g}$ protein/ml; L: solid bars). Data are presented as mean ( \pm S.E.M.) of four independent experiments. ${ }^{*} P<0.05$ and ${ }^{* *} P<0 \cdot 01$ for each treatment versus basal progesterone production in the appropriate control cells.

progesterone output from human luteinized ovarian cells. To the best of our knowledge, this is the first study to report that HDL can stimulate a comparable steroid response to that elicited by LDL at the same protein concentration.

Because of their differing compositions in terms both of apolipoproteins and cholesterol/cholesteryl esters (RiceEvans \& Bruckdorfer 1992), at equal protein concentrations, the cholesterol concentration of LDL would be expected to be approximately fourfold higher than the cholesterol concentration of HDL. Hence, the fact that HDL and LDL evoked similar progesterone responses at equal protein concentrations suggested that either HDL may be more efficient than LDL at delivering cholesterol substrate to human granulosa-lutein cells, or that HDL may stimulate progesterone production by a cholesterolindependent mechanism. Certainly, the delivery of fluorescent cholesterol from HDL into human granulosa-lutein cells has been previously documented (Azhar et al. 1998) and one might expect delivery of cholesterol via SR-BI to be more efficient than uptake via the receptor-mediated endocytosis of LDL. However, this does not exclude the possibility that HDL might also act via a cellular mechanism(s) independent of the delivery of cholesterol.

To determine whether HDL is a more efficient source of cholesterol than LDL, or whether HDL might act via a cholesterol-independent mechanism(s), cells were first challenged with HDL and LDL at concentrations normalized for their cholesterol content. In these experiments, 
HDL was shown to be more potent than LDL in stimulating progesterone production at an equivalent concentration of cholesterol. If this observation reflects a difference in the efficiency of cholesterol provision as a steroidogenic substrate, then it should be possible to abolish the responses to both LDL and HDL by cotreating cells with high concentrations of a membrane permeable hydroxysterol, such as 20R-, 22R- or 25hydroxycholesterol. The rate-determining enzymatic step in the synthesis of progesterone is the conversion of cholesterol to pregnenolone, catalysed by cytochrome $\mathrm{P} 450$ cholesterol side-chain cleavage $\left(\mathrm{P}^{4} 50_{\mathrm{CSCC}}\right)$ in the inner mitochondrial membrane (Burstein \& Gut 1971, Voutilainen et al. 1986, Miller 1988). The ratedetermining physical step in this reaction is the transport of cholesterol across the mitochondrial membranes (Burstein \& Gut 1971, Hume \& Boyd 1978, Stocco \& Clark 1996, Culty et al. 1999). $22 \mathrm{ROHC}$ is a membrane permeable sterol which is one of the intermediates in the action of $\mathrm{P} 450_{\mathrm{CSCC}}$ and which is used routinely in studies of steroidogenic cells to bypass the rate-determining provision of cholesterol to the $\mathrm{P} 450_{\mathrm{CsCC}}$ enzyme complex (Miller 1988, Tuckey \& Atkinson 1989). The fact that LDL was unable to influence progesterone production in cells treated with $22 \mathrm{ROHC}$ is consistent with the assumption that LDL stimulates steroidogenesis predominantly (if not solely) by the provision of cholesterol substrate. In contrast, the ability of HDL to further enhance progesterone biosynthesis in conditions where the availability of cholesterol substrate was no longer limiting suggests that HDL must be capable of acting by a mechanism or mechanisms other than by the net delivery of cholesterol to the steroidogenic pathway.

As noted above, trophic hormones, including hCG and adrenocorticotrophic hormone (ACTH), have previously been reported to induce the expression of lipoprotein receptors (Cummings et al. 1982, Ohashi et al. 1982, Golos \& Strauss 1985, Golos et al. 1985, 1986, Takagi \& Strauss 1989, Rudling et al. 1990, Foster et al. 1993). Moreover, it has been reported that pre-treatment of granulosa-lutein cells for $24 \mathrm{~h}$ with hCG (or db-cAMP) facilitates rapid uptake of HDL-cholesteryl ester within $1 \mathrm{~h}$, followed by increased intracellular lipid staining at 3-6 h of subsequent HDL treatment (Reaven et al. 1995, 1998, Azhar et al. 1998). Based on these observations, we hypothesized that pre-treatment with hCG for $24 \mathrm{~h}$ might potentiate the subsequent steroidogenic response to HDL and, moreover, might facilitate an acute response to HDL. However, pre-treatment of granulosa-lutein cells with hCG neither enhanced the $24 \mathrm{~h}$ response to HDL and LDL, nor did it accelerate the ability of these plasma lipoproteins to elicit significant increases in progesterone output. The failure of hCG pre-treatment to potentiate the progesterone response to HDL under circumstances reported to enhance delivery of HDL-cholesterol into human granulosa-lutein cells further supports our hypothesis that the steroidogenic response to HDL is not merely determined by the net delivery of cholesterol into these cells.

Having raised the possibility that HDL may not simply act as a source of cholesterol substrate, we designed experiments to look at the cellular signalling pathways via which HDL might be stimulating progesterone production. In the current study, the progesterone responses to HDL and db-cAMP were additive, consistent with prior observations by Azhar et al. (1998). This finding suggests that HDL cannot be stimulating steroidogenesis via the cAMP-PKA signalling pathway; if it were, then co-treatment with HDL should not have been able to stimulate progesterone production over and above that observed in the presence of a maximally effective concentration of db-cAMP.

As an alternative to the CAMP-PKA signal transduction pathway, the calcium-PKC pathway has been implicated in the stimulation of gonadal steroid biosynthesis (Brunswig et al. 1986, Lopez-Ruiz et al. 1992, Jamaluddin et al. 1994, Yuan \& Connor 1997). Furthermore, PKC may also be involved in the efflux of cholesterol to HDL (Mendez et al. 1991). In the current study, downregulation of PKC activity did not influence the foldincrease in progesterone production induced by either HDL or LDL. Hence, it seems highly unlikely that PKC either mediates or modulates the progesterone response to plasma lipoproteins in human granulosa-lutein cells.

In conclusion, based on several distinct lines of evidence reported in this study, HDL appears to be capable of stimulating ovarian steroidogenesis via a cellular mechanism(s) other than via the delivery of cholesterol as a steroidogenic substrate. This mechanism, which appears to act independently of the cAMP and PKC signalling pathways, is currently under investigation in our laboratories.

\section{Acknowledgements}

We wish to acknowledge the staff at the Lister Private Hospital and Hallam Medical Centre for the collection of ovarian cells. This work was supported, in part, by a BBSRC studentship to JR.

\section{References}

Abayasekara DRE, Michael AE, Webley GE \& Flint APF 1993a Mode of action of prostaglandin $\mathrm{F}_{2 \alpha}$ : role of protein kinase C. Molecular and Cellular Endocrinology 97 81-91.

Abayasekara DRE, Jones PM, Persaud SJ, Michael AE \& Flint APF $1993 b$ Prostaglandin $F_{2 \alpha}$ activates protein kinase $C$ in human ovarian cells. Molecular and Cellular Endocrinology 91 51-57.

Acton S, Rigotti A, Landschulz KT, Xu S, Hobbs HH \& Krieger M 1996 Identification of scavenger receptor SR-BI as a high density lipoprotein receptor. Science 271 518-520.

Azhar S, Tsai L, Medicherla S, Chandrasekher Y, Giudice L \& Reaven E 1998 Human granulosa cells use high-density lipoprotein cholesterol for steroidogenesis. Journal of Clinical Endocrinology and Metabolism 83 983-991. 
Babitt J, Trigatti B, Rigotti A, Smart EJ, Anderson RGW, Xu S \& Krieger M 1997 Murine SR-BI, a high-density lipoprotein receptor that mediates selective lipid uptake is $\mathrm{N}$-glycosylated and fatty acylated and colocalises with plasma membrane caveolae. Journal of Biological Chemistry 272 13242-13249.

Bao B, Thomas MG, Griffith MK, Burghardt RC \& Williams GL 1995 Steroidogenic activity, insulin-like growth factor-I production and proliferation of granulosa and thecal cells obtained from dominant preovulatory and non-ovulatory follicles during the bovine oestrous cycle: effects of low-density and high-density lipoproteins. Biology of Reproduction 53 1271-1279.

Barter PJ \& Rye KA 1996 Molecular mechanisms of reverse cholesterol transport. Current Opinion in Lipidology 7 82-87.

Brannian JD 1997 Expression and function of a scavenger lipoprotein pathway in porcine luteal cells. Biology of Reproduction 56 221-228.

Brannian JD \& Stouffer RL 1993 Native and modified (acetylated) low density lipoprotein-supported steroidogenesis by macaque granulosa cells collected before and after the ovulatory stimulus: correlation with fluorescent lipoprotein uptake. Endocrinology 132 591-597.

Brannian JD, Shiigi SM, \& Stouffer RL 1992 Gonadotrophin surge increases fluorescent-tagged low-density lipoprotein uptake by macaque granulosa cells from preovulatory follicles. Biology of Reproduction 47 355-360.

Brown MS, Kovanen PT \& Goldstein JL 1979 Receptor-mediated uptake of lipoprotein cholesterol and its utilization for steroid synthesis in the adrenal cortex. Recent Progress in Hormone Research $35215-217$.

Brunswig B, Mukhopadhyay AL, Budnik LT, Bohnet HG \& Leidenberger FA 1986 Phorbol ester stimulates progesterone production by isolated bovine luteal cells. Endocrinology 118 743-749.

Burstein S \& Gut M 1971 Biosynthesis of pregnenolone. Recent Progress in Hormone Research 27 303-349.

Carr BR, Sadler RK, Rochelle DB, Stalmach MA, MacDonald PC \& Simpson ER 1981 Plasma lipoprotein regulation of progesterone biosynthesis by human corpus luteum tissue in organ culture. Journal of Clinical Endocrinology and Metabolism 52 875-881.

Cooke BA 1990 Is cyclic AMP an obligatory second messenger for luteinizing hormone? Molecular and Cellular Endocrinology 69 C11-C15.

Cooke BA 1999 Signal transduction involving cyclic AMP-dependent and cyclic AMP-independent mechanisms in the control of steroidogenesis. Molecular and Cellular Endocrinology 151 25-35.

Culty M, Li H, Boujrad N, Amri H, Vidic B, Bernassau JM, Reversat JL \& Papadopoulos V 1999 In vitro studies on the role of the peripheral-type benzodiazepine receptor in steroidogenesis. Journal of Steroid Biochemistry and Molecular Biology 69 123-130.

Cummings SW, Hatley W, Simpson ER \& Ohashi M 1982 The binding of high and low density lipoproteins to human placental membrane fractions. Journal of Clinical Endocrinology and Metabolism 54 903-908.

Davis JS 1994 Mechanisms of hormone action: luteinizing hormone receptors and second-messenger pathways. Current Opinion in Obstetrics and Gynecology 6 254-261.

Enk L, Crona N \& Hillensjo T 1987 High- and low-density lipoproteins stimulate progesterone production in human cultured granulosa cells. Human Reproduction 2 291-295.

Fielding CJ \& Fielding PE 1995 Molecular physiology of reverse cholesterol transport. Journal of Lipid Research 36 211-228.

Foster JD, Strauss JF III \& Paavola LG 1993 Cellular events involved in hormonal control of receptor mediated endocytosis: regulation occurs at multiple sites in the low-density lipoprotein pathway, including steps beyond the receptor. Endocrinology 132 337-350.

Golos TG \& Strauss JF III 1985 Regulation of low density lipoprotein receptor synthesis in cultured luteinised human granulosa cells by human chorionic gonadotrophin and 8-bromo-cyclic AMP. Journal of Biological Chemistry 260 14399-14402.
Golos TG, Soto EA, Tureck RW \& Strauss JF III 1985 Human chorionic gonadotrophin and 8-bromo-adenosine-3', $5^{\prime}$-monophosphate stimulate $\left[{ }^{125} \mathrm{I}\right]$ low density lipoprotein uptake and metabolism by luteinised human granulosa cells in culture. Journal of Clinical Endocrinology and Metabolism 61 633-638.

Golos TG, August AM \& Strauss JF III 1986 Expression of low density lipoprotein receptor in cultured human granulosa cells: regulation by human chorionic gonadotrophin, cyclic AMP, and sterol. Journal of Lipid Research 27 1089-1096.

Graf GA, Conell PM, Van Der Westhuijzen DR \& Smart E 1999 The class B, type I scavenger receptor promotes the selective uptake of high density lipoprotein cholesterol esters into caveolae. Journal of Biological Chemistry 274 12043-12048.

Havel RJ, Eder HA \& Bragdon JH 1955 The distribution and chemical composition of ultracentrifugally separated lipoproteins in human serum. Journal of Clinical Investigation 34 1345-1353.

Hume R \& Boyd GS 1978 Cholesterol metabolism and steroidhormone production. Biochemical Society Transactions 6 893-898.

Hwang J \& Menon KMJ 1983 Characterisation of low-density and high-density lipoprotein receptors in the rat corpus luteum and regulation by gonadotrophin. Journal of Biological Chemistry 258 8020-8027.

Jamaluddin M, Molnar M, Marrone BL \& Hertelendy F 1994 Signal transduction in avian granulosa cells: effects of protein kinase C inhibitors. General and Comparative Endocrinology 93 471-479.

Janero DR 1990 Malondialdehyde and thiobarbituric acid-reactivity as diagnostic indices of lipid peroxidation and peroxidative tissue injury. Free Radical Biology \& Medicine 9 515-540.

Jaspard B, Collet X, Barbaras R, Manent J, Vieu C, Parinaud J, Chap H \& Perret B 1996 Biochemical characterization of pre- $\beta 1$ high-density lipoprotein from human ovarian follicular fluid: evidence for the presence of a lipid core. Biochemistry $\mathbf{3 5}$ 1352-1357.

Jaspard B, Fournier N, Vieitez G, Atger V, Barbaras R, Vieu C, Manent J, Chap H, Perret B \& Collet X 1997 Structural and functional comparison of HDL from homologous human plasma and follicular fluid. A model for extravascular fluid. Arteriosclerosis, Thrombosis and Vascular Biology 17 1605-1613.

Leung PCK \& Steele GL 1992 Intracellular signalling in the gonads. Endocrine Reviews 13 476-498.

Lopez-Ruiz MP, Choi MSK, Rose MP, West AP \& Cooke BA 1992 Direct effect of arachidonic acid on protein kinase $\mathrm{C}$ and $\mathrm{LH}-$ stimulated steroidogenesis in rat Leydig cells; evidence for tonic inhibitory control of steroidogenesis by protein kinase C. Endocrinology 130 1122-1130.

Markwell MA, Haas SM, Bieber LL \& Tolbert NE 1978 A modification of the Lowry procedure to simplify protein determination in membrane and lipoprotein samples. Analytical Biochemistry 87 206-210.

Mendez AJ, Oram JF \& Bierman EL 1991 Role of the protein kinase $\mathrm{C}$ signalling pathway in high-density lipoprotein receptor-mediated efflux of intracellular cholesterol. Transactions of the Association of American Physicians 104 48-53.

Miller WL (1988) Molecular biology of steroid hormone synthesis. Endocrine Reviews 3 295-318.

Ohashi W, Carr BR \& Simpson ER 1982 Lipoprotein sites in human corpus luteum membrane fractions. Endocrinology 110 1477-1482.

Pallikaros Z, Schulster D, Baldwin SA, Helliwell RJA, Michael AE \& Cooke BA 1995 Characterization of site-directed antibodies to the $\mathrm{LH}$ receptor in functionally active gonadal cells and their differential effects on LH-stimulated signal transduction in Leydig tumour (MA10) cells. Molecular and Cellular Endocrinology 114 57-68.

Parinaud J, Perret B, Ribbes H, Chap H, Pontonnier G \& Douste-Blazy L 1987 High-density lipoprotein and low-density lipoprotein utilization by human granulosa cells for progesterone synthesis in serum-free culture: respective contributions of free and esterified cholesterol. Journal of Clinical Endocrinology and Metabolism 64 409-417. 
Pascher E \& Sturm CG 1997 Expression of mRNA for ovarian steroid-stimulating factor (apolipoprotein A-I and apolipoprotein A-I-like protein) in human granulosa cells. Experimental Clinical Endocrinology and Diabetes 105 122-124.

Pieters MN, Schouten D \& Van Berkel TLC 1994 In vitro and in vivo evidence for the role of HDL in reverse cholesterol transport. Biochimica et Biophysica Acta 1225 125-134.

Reaven E, Tsai L \& Azhar S 1995 Cholesterol uptake by the selective pathway of ovarian granulosa cells: early intracellular events. Journal of Lipid Research 36 1602-1617.

Reaven E, Nomoto A, Leers-Sucheta S, Temel R, Williams DL \& Azhar S 1998 Expression and microvillar localisation of scavenger receptor, class B, type I (a high density lipoprotein receptor) in luteinised and hormone-desensitised rat ovarian models. Endocrinology 139 2847-2856.

Rice-Evans C \& Bruckdorfer KR 1992 Free radicals, lipoproteins and cardiovascular dysfunction. Molecular Aspects of Medicine 13 1-111.

Rudling MJ, Reihner E, Einarsson K, Ewerth S \& Angelin B 1990 Low-density receptor binding activity in human tissues: quantitative importance of hepatic receptors and evidence for regulation of their expression in vivo. PNAS 87 3469-3473.

Savion N, Lui GM, Latherty R \& Gospodarowicz D 1981 Factors controlling proliferation and progesterone production by bovine granulosa cells in serum-free medium. Endocrinology 109 409-420.

Savion N, Latherty R, Cohen D, Lui GM \& Gospodarowicz D 1982 Role of lipoproteins and 3-hydroxy-3-methylglutaryl Coenzyme A reductase in progesterone production by cultured bovine granulosa cells. Endocrinology 110 13-22.

Schuler LA, Langenberg KK, Gwynne JT \& Strauss JF III 1981 High-density lipoprotein utilisation by dispersed rat luteal cells. Biochimica et Biophysica Acta 664 583-601.

Simpson ER, Rochelle DB, Carr BR \& MacDonald PC 1980 Plasma lipoproteins in follicular fluid of human ovaries. Journal of Clinical Endocrinology and Metabolism 51 1469-1471.

Soto E, Silvain SL, Tureck RW \& Strauss JF III 1984 Stimulation of progesterone synthesis in luteinized human granulosa cells by human chorionic gonadotropin and 8-bromo-adenosine- $3^{\prime}, 5^{\prime}-$ monophosphate: the effect of low density lipoprotein. Journal of Clinical Endocrinology and Metabolism 58 831-837.

Stocco DM \& Clark BJ 1996 Regulation of the acute production of steroids in steroidogenic cells. Endocrine Reviews 17 221-244.
Takagi K \& Strauss JF III 1989 Control of low density lipoprotein receptor gene expression in steroidogenic cells. Canadian Journal of Physiology and Pharmacology 67 968-973.

Tuckey RC \& Atkinson HC 1989 Pregnenolone synthesis from cholesterol and hydroxycholesterols by mitochondria from ovaries following the stimulation of immature rats with pregnant mare's serum gonadotropin and human choriogonadotropin. European Journal of Biochemistry 186 255-259.

Tureck RW \& Strauss JF III 1982 Progesterone synthesis by luteinized human granulosa cells in culture: the role of de novo sterol synthesis and lipoprotein-carried sterol. Journal of Clinical Endocrinology and Metabolism 54 367-372.

Veldhuis JD, Gwynne JT, Strauss JF III \& Demers LM 1984 Role of oestradiol as a biological amplifier of gonadotrophin action in the ovary: in vitro action using swine granulosa cells and homologous lipoproteins. Endocrinology 114 2312-2322.

Volpe A, Coukos G, Uccelli E, Droghini F, Adamo R \& Artini PG 1991 Follicular fluid lipoproteins in preovulatory period and their relationship with follicular maturity and progesterone production by human granulosa-luteal cells in vivo and in vitro. Journal of Endocrinological Investigations 14 737-742.

Voutilainen R, Tapanainem J, Chung B, Matteson KJ \& Miller WL 1986 Hormonal regulation of P450 scc and P450c17 in cultured human granulosa cells. Journal of Clinical Endocrinology and Metabolism 63 202-207.

Webley GE, Luck MR \& Hearn JP 1988 Stimulation of cultured human granulosa cells with melatonin and catecholamines. Journal of Reproduction and Fertility 84 669-677.

Wiltbank MC, Diskin MG, Flores JA \& Niswender GD 1990 Regulation of the corpus luteum by protein kinase C. II. Inhibition of lipoprotein-stimulated steroidogenesis by prostaglandin F2 alpha. Biology of Reproduction 42 239-245.

Yuan W \& Connor ML 1997 Protein kinase C activity and its effect on progesterone production by large and small porcine luteal cells. Proceedings of the Society for Experimental Biology and Medicine 216 86-92.

Received in final form 30 November 2001 Accepted 5 December 2001 